This is the author's final, peer-reviewed manuscript as accepted for publication. The publisher-formatted version may be available through the publisher's web site or your institution's library.

\title{
Resistance to multiple cereal aphids in wheat-alien substitution and translocation lines
}

Leonardo A. Crespo-Herrera, C. Michael Smith, Ravi P. Singh, Inger Åhman

\section{How to cite this manuscript}

If you make reference to this version of the manuscript, use the following information:

Crespo-Herrera, L. A., Smith, C. M., Singh, R. P., \& Åhman, I. (2013). Resistance to multiple cereal aphids in wheat-alien substitution and translocation lines. Retrieved from http://krex.ksu.edu

\section{Published Version Information}

Citation: Crespo-Herrera, L. A., Smith, C. M., Singh, R. P., \& Åhman, I. (2013). Resistance to multiple cereal aphids in wheat-alien substitution and translocation lines. Arthropod-Plant Interactions, 7(5), 535-545.

Copyright: @ Springer Science+Business Media Dordrecht 2013

Digital Object Identifier (DOI): doi:10.1007/s11829-013-9267-y

Publisher's Link: http://link.springer.com/article/10.1007/s11829-013-9267-y

This item was retrieved from the K-State Research Exchange (K-REx), the institutional repository of Kansas State University. K-REx is available at http://krex.ksu.edu 


\title{
Resistance to multiple cereal aphids in wheat-alien substitution and translocation lines
}

\author{
Leonardo A. Crespo Herrera ${ }^{1}$, C. Michael Smith ${ }^{2}$, Ravi P. Singh ${ }^{3}$, Inger Åmman ${ }^{1}$
}

${ }^{1}$ Department of Plant Breeding, Swedish University of Agricultural Sciences, P.O. Box 101, SE 23053 Alnarp, Sweden

${ }^{2}$ Department of Entomology, Kansas State University, Manhattan, KS 66506-4004, USA

${ }^{3}$ International Maize and Wheat Improvement Center (CIMMYT), Apdo. Postal 6-641, 06600, Mexico DF, Mexico

*Corresponding author: leo.crespo@slu.se, +46 40415512

\section{Abstract}

11 Rhopalosiphum padi, Schizaphis graminum, and Sitobion avenae are three of the most destructive aphid species of wheat (Triticum aestivum L.). They can significantly reduce wheat yields directly by feeding and indirectly by transmitting viruses. This study aimed to search for resistance to these aphid species among lines derived from different rye (Secale cereale) origins and from Aegilops speltoides, all in the genetic background of the wheat cultivar Pavon F76. Resistance was quantified as aphid weight (R. padi, S. avenae, S. graminum), and number of aphids and percentage of infested leaf area exhibiting chlorosis (S. graminum). The most resistant genotypes reduced R. padi and S. avenae weight by $24.2 \%$ and $34.3 \%$, respectively, at the seedling stage, compared to Pavon F76 control plants. Strong S. graminum resistance was found only in Ae. speltoides-derived lines, the most resistant of which (7A.7S-L5) sustained just 3\% chlorosis and reduced S. graminum colony weight by $67.7 \%$. One line carrying the $1 \mathrm{AL} .1 \mathrm{RS}_{\mathrm{am}}$ wheat-rye translocation from Amigo wheat (originally from Insave rye) reduced S. avenae weight by 23.2 and $21.8 \%$ in seedling and adult plants, respectively. Single genotypes carrying the complete 1R chromosome or the 1RS chromosome arm derived from E12165 wheat and Presto triticale proved to be resistant to both $R$. padi and $S$. avenae at the seedling stage. Further research should be conducted to unravel the genetic basis of resistance to these aphids in 1RS genotypes. The sources of resistance identified here may be useful for incorporating multiple aphid species resistance in wheat breeding programs, particularly for $R$. padi and $S$. avenae, to which no resistant wheats have been bred.

Keywords: Rhopalosiphum pad; Schizaphis graminum; Sitobion avenae; Triticum aestivum; Secale cereale; 
Aphids are a major biotic constraint to wheat (Triticum aestivum L.) production because they inflict direct feeding damage and can transmit viruses. Among those of particular importance are: the bird cherry - oat aphid (Rhopalosiphum padi L.), the greenbug (Schizaphis graminum [Rondani]), and the English grain aphid (Sitobion avenae [Fabricius]), which are widely distributed in wheat producing areas, with some differentiation depending on the geographic region (Blackman and Eastop 2007). These aphids can reduce wheat yields by 30-40\% (Kieckhefer and Gellner 1992; Voss et al. 1997) and by up to $60 \%$ when direct damage is combined with losses from virus infection (Riedell et al. 2003). Damage due to R. padi and S. avenae is evident mainly as reduced plant growth and grain yields, whereas S. graminum feeding also causes plant chlorosis and necrotic spots at the feeding site (Voss et al. 1997; Blackman and Eastop 2007; Franzen et al. 2008). Given that plant resistance to arthropod pests is an environmentally and economically sound plant protection strategy, it is important to identify sources of aphid resistance for developing aphid-resistant wheat cultivars (Berzonsky et al. 2003; Porter et al. 2009).

Wheat-alien chromosome translocations and substitutions have been successfully exploited in the development of new wheat cultivars, and alien genetic sources such as rye (Secale cereale L.) were shown to enhance yield potential and confer resistance to biotic stresses (Friebe et al. 1996; Kim et al. 2004). A widely utilized source is the 1R chromosome from Petkus rye, which is deployed in hundreds of cultivars, such as Kavkaz wheat (Rabinovich 1998). Resistance to various biotic stresses has also been found in Aegilops speltoides Tausch (Friebe et al. 1996). Breeding for S. graminum-resistant wheat cultivars began in the 1950s (Porter et al. 1997; Berzonsky et al. 2003); two of the resistance genes (Gb2 and Gb6) originate from the 1RS chromosome arm of Insave rye (Sebesta and Wood 1978; Lu et al. 2010), whilst Gb5 was derived from the 7SL chromosome arm of Ae. speltoides (Tyler et al. 1985, 1987; Lukaszewski 1995). No R. padi-resistant wheat cultivars currently exist, but several triticale and ryewheat derived lines express resistance to R. padi (Hesler 2005; Hesler and Tharp 2005; Hesler et al. 2007). Similarly, no wheat cultivars have been bred for resistance to $S$. avenae, though a resistance gene from durum wheat (Triticum turgidum L. ssp. durum [Desf.]) was recently mapped (Liu et al. 2012). Previous studies have searched for S. avenae resistance in several wild Triticum relatives, but not in wheat-rye derived germplasm (Di Pietro et al. 1998; Migui and Lamb 2003; Migui and Lamb 2004). One exception is Amigo wheat (Lowe 1981; Hu et al. 2004), but S. avenae resistance has not been attributed to the $1 \mathrm{AL} .1 \mathrm{RS}$ translocation carried by this cultivar. Plant materials are rarely evaluated for resistance to more than two aphid species. However, Smith et al. (2004b) evaluated 20 R. padi-resistant accessions, belonging to six Aegilops spp. and one T. araraticum Jakubz. They reported that Aegilops neglecta Req. accession 8052 also possessed resistance to S. avenae and the Russian wheat aphid, Diuraphis noxia (Kudjumov). Similarly, Migui and Lamb (2003) evaluated 19 wild wheat relatives for resistance to R. padi, S. avenae, and S. graminum, and found resistance to S. avenae and R. padi, or S. avenae and S. graminum in individual accessions, but none resistant to all three aphid species. Although diploid species appear to have the highest frequency of resistance (Migui and Lamb 2003), introgressing resistance genes from multiple wild 
Burd and Porter (2006) studied S. graminum - host resistance interactions and found considerable intraspecific plant variation and several S. graminum virulence patterns. A chronological review of the field deployment of $S$. graminum resistant wheat cultivars and the detection of new S. graminum biotypes states that "The use of greenbug [S. graminum]-resistant wheat cultivars could not have contributed to the development of new biotypes" (Porter et al. 1997). There is also variation in the virulence patterns of various S. avenae populations (Lowe 1981; Caillaud et al. 1995; Xu et al. 2011). However no S. avenae biotype designations have been made, since the biotype concept refers to the specific outcomes from the aphid resistance/susceptibility interaction with germplasm differing in the resistance genes they carry. No variation in $R$. padi virulence has been reported to date.

This study aimed to search for resistance to R. padi, S. avenae, and S. graminum in a set of wheat-alien translocation and substitution lines previously developed in the same genetic background (spring wheat Pavon F76). Resistance to multiple aphid species within a single genotype is a highly desired trait and can greatly facilitate the development of new, aphid-resistant cultivars, particularly in regions where distributions of different aphid species overlap.

\section{Materials and methods}

Plant materials

We screened germplasm previously developed in the genetic background of the spring wheat cultivar Pavon F76 for resistance to R. padi, S. avenae, and S. graminum. The material consisted of 54 wheat-rye centric translocation and substitution lines, seven wheat-rye, and four Ae. speltodies-wheat recombinant derived lines (Table 1) from the genetic resources program of the International Maize and Wheat Improvement Center (CIMMYT, Mexico). These lines were second generation offspring from self-pollinated single plants that had been analyzed by C-banding to confirm published substitution/translocation descriptions. Descriptions of the genotypes can be found in Lukaszewski (1993, 1995, 1997, 2000, 2006, 2008), Brunell et al. (1999), Kumlay et al. (2003), Kim et al. (2004), and Lukaszewski et al. (2004). This paper will follow the same nomenclature, where subscripts represent the origin of wheat chromosomes (A, B, and D) and rye (R) genomes ( $\mathrm{L}=$ chromosome long arm; $\mathrm{S}=$ chromosome short arm) (Table 1).

Aphid rearing

Aphids were reared in cages under glasshouse conditions at ca. $22^{\circ} \mathrm{C}$, with a minimum of $16 \mathrm{~h}$ of light, supplemented when needed with $400 \mathrm{~W}$ high-pressure sodium lamps. R. padi and S. avenae were maintained on oat plants in the Department of Plant Breeding and Biotechnology at the Swedish University of Agricultural Sciences (SLU). Two sources of Swedish R. padi, collected $600 \mathrm{~km}$ apart, were used in the screenings; they were collected from their winter host (Prunus padus L.) in order to avoid infection by barley yellow dwarf virus. S. avenae adults were collected from wheat fields around Alnarp, and a colony was started from nymphs born on a sugar diet to obtain virus free aphids. Virus-free starter colonies of S. graminum biotype E were obtained from USDA-ARS and 
common and virulent to wheat carrying resistance genes $g b 1$ and $G b 2$, but non-virulent to genes $G b 3-G b 7$ (Burd and

100 Porter 2006; Weng et al. 2005).

101 Aphid resistance screening methods

102 All experiments included a Pavon F76 control, since the alien material was transferred into that genetic background.

103 Screening consisted of two phases for each aphid species - Phase 1, where all lines were screened for resistance and

104 Phase 2, where genotypes selected in Phase 1 were screened three times with R. padi and S. avenae, or once with S.

105 graminum, to confirm or reject statistically significant results from Phase 1. Other lines from the stock having the

106 same alien origin as the statistically more resistant lines in Phase 1 were also included. $R$. padi tests preceded the $S$.

107 avenae tests and some lines resistant to $R$. padi were also included in the S. avenae Phase 2 test.

108 Evaluation of seedling plant resistance to R. padi, S. avenae, and S. graminum

109 Resistance to R. padi and S. avenae was measured as reduced growth rate at SLU. Candidate lines were divided into

110 subsets in Phase 1, as it was only possible to screen a maximum of 24 entries per week. Seeds of each genotype were

111 placed on humid filter paper in Petri dishes, cold treated at $5^{\circ} \mathrm{C}$ for three days, maintained at room temperature for

112 two days, and then individually planted in a plastic $10 \mathrm{~cm}$-diameter pot (300 ml) in Weibull's Kronmull ${ }^{\circledR}$ potting soil

113 with Leca. Pots were arranged in a randomized complete block design with four replicates (one plant per replicate).

114 Seedlings were grown in a walk-in climate controlled chamber at $22^{\circ} \mathrm{C}, 80 \% \mathrm{RH}$, and $16 \mathrm{~h}$ light at the intensity of

$115250 \mu \mathrm{mol}$ photons $\mathrm{m}^{-2} \mathrm{~s}^{-1}$ at plant level.

116 Seven to eight days after transplanting (second - third leaf stage), each plant was exposed to five nymphs born within 117 a time span of 24 hours. These nymphs were obtained from alate females in the rearing colony maintained overnight

118 on oat plants. Newborn nymphs were confined at the base of the test plants in transparent cylindrical acrylic cages (2

119 cm diameter, $5 \mathrm{~cm}$ length), sealed with cotton wool at the bottom and the top. Nymphs were individually weighed on

120 a Mettler M3 microbalance four days after infestation.

121 S. graminum experiments were performed under glasshouse conditions (ca. $22^{\circ} \mathrm{C}, 80 \% \mathrm{RH}$, and $16 \mathrm{~h}$ light) at $\mathrm{KSU}$.

122 In Phase 1, 8-10 seeds of each genotype were sown in tufts in flats $(36 \mathrm{~cm} \times 51 \mathrm{~cm})$ filled with Pro-mix ${ }^{\circledR}$ BX

123 (Hummert International), in a complete randomized experimental design with four replicates. The stock was divided

124 spatially in two subsets since there was only room for 35 genotypes per flat. The S. graminum-resistant control,

125 wheat line GRS-1201, containing the Gb6 resistance gene from Insave rye (Lu et al. 2010) was included in each flat.

126 The plants were infested at the second to third leaf stage with previously infested leaves of Jagger wheat, at an

127 average density of 5 nymphs per tuft. We scored the percentage of chlorosis on infested leaves 14 days after

128 infestation. For Phase 2 screening, eight genotypes were selected based on their genetic background and a low

129 percentage of chlorosis in Phase 1. Seeds of each genotype were germinated in Petri dishes for six days, and

130 seedlings of each entry were then planted individually in $10 \mathrm{~cm}$ pots. Each pot was covered with a fine-mesh of

131 organdy fabric supported by wooden stakes allowing undisturbed growth of plants. Plants at the second to third leaf

132 stage were then infested with two third or fourth instar nymphs. The experiment was established as a randomized 
complete block design with 10 replicates. Percentage of chlorosis, number of aphids, and weight of the colony were recorded 10 days after infestation.

We selected and evaluated 12 genotypes for adult plant $S$. avenae resistance, using a similar rationale for selections as for Phase 2 seedling tests. Screening additional lines was not possible due to space and management requirements or lack of synchrony with the phenology of the control line.

139 Seeds were germinated as described above, transplanted singly into $16 \mathrm{~cm}$ plastic pots (2 L), and grown under

140 glasshouse conditions (in a randomized complete block design with four replicates) until ear emergence (Zadoks growth Scale GS: 53-55, Zadoks et al. 1974). Plants were then infested with five newborn S. avenae (obtained using the above methods). Nymphs were confined to one emerging ear and its flag leaf with a perforated polyethylene bag (18 x $26 \mathrm{~cm}$, Baumann Saatzuchtbedarf), and plants were then transferred to a walk-in climate controlled chamber $\left(22^{\circ} \mathrm{C}, 80 \% \mathrm{HR}\right.$, and $16 \mathrm{~h}$ light at the intensity of $250 \mu \mathrm{mol}$ photons $\mathrm{m}^{-2} \mathrm{~s}^{-1}$ at plant level), where they were kept for four days before the aphids were weighed on a Mettler M3 microbalance. The Pavon F76 control was sown weekly three more times after the test plants, so that growth stages could be matched. Entries were grouped in two subsets according to their phenology because they had different days until flowering.

\section{Statistical analysis}

We used SAS/STAT ${ }^{\circledR}$ software, version 9.2 (SAS Institute Inc. 2009) for all statistical analyses. Analysis of variance for aphid weights from Phase 1 experiments with R. padi and S. avenae was conducted using the GLM procedure, and least-square means per genotype were calculated. Statistical differences between genotype and control means were tested by the comparatively less stringent $t$-test to identify all potentially resistant lines (type 1 error was not anticipated, as Phase 2 experiments would correct). The ratio between the mean of aphids on a genotype and on a control plant was calculated as aphid weight percentage of Pavon F76. Results from Phase 2 experiments were analyzed with the MIXED procedure, where genotypes were included in the model as fixed effects, and blocks and round of evaluation as random effects. Blocks were nested within round of evaluation. Least square means were compared with those of Pavon F76 in a Dunnett's test. We analyzed both phases of the S. graminum evaluation with the GLM procedure. In Phase 1, plant chlorosis was scored and means were compared with $t$-tests. In Phase 2, numbers of $S$. graminum and the weight of the $S$. graminum colony were quantified and genotype means were compared with those of Pavon F76 in a Dunnett's test. One degree of freedom contrasts were made between genotypes 7A.7S-L7, 7A.7S-L5, 7A.7S-Gb5, and the resistant control (GRS-1201).

\section{Results}

164 In Phase 1 evaluations, $R$. padi weights ranged from $65.2 \%$ to $119.3 \%$ of the Pavon F76 control, though we 165 detected statistical differences between genotypes in only the first two subsets (subset $1: d f=15,213 ; F=3.11$; $166 p<0.0001$; subset $2: d f=17,273 ; F=3.63 ; p<0.0001$; subset $3: d f=17,284 ; F=1.55 ; p=0.0771$; subset $4: d f=16$, 
significantly ( $p \leq 0.05$; $t$-test) compared to the Pavon F76 control (Table 1 ). These lines, six other lines carrying rye chromatin of similar origin and the control (15 total genotypes) were selected for Phase 2 screening. Significant differences were detected with the SAS MIXED procedure $(d f=14,146 ; F=3.29 ; p<0.0001)$. According to the Dunnett's test, genotypes $1 \mathrm{R}_{\mathrm{e}}(1 \mathrm{~A}), 1 \mathrm{R}_{\mathrm{e}}(1 \mathrm{~B}), 1 \mathrm{R}_{\mathrm{pr}}(1 \mathrm{D}), 1 \mathrm{R}_{\mathrm{pr}} \cdot 1 \mathrm{D}_{5+10-2}(1 \mathrm{D}), 1 \mathrm{AL} \cdot 1 \mathrm{RS}_{\mathrm{e}}$, and $1 \mathrm{BL}_{\mathrm{v}} \cdot 1 \mathrm{RS}_{\mathrm{e}}$ reduced $R$. padi weight significantly (23.9-14.4\%; Table 2), compared to the Pavon F76 control.

S. avenae mean weights in Phase 1 evaluations ranged from $69.8 \%$ to $157.4 \%$ of Pavon F76. However, statistical differences $(p \leq 0.05)$ between genotypes were observed only in subset $1(d f=18,199 ; F=3.63 ; p \leq 0.001)$, where only the $1 \mathrm{BL}_{\mathrm{v}} \cdot 1 \mathrm{RS}_{\mathrm{e}}$ genotype reduced $S$. avenae mean weight significantly more than Pavon F76 (Table 1). Selection of genotypes for Phase 2 was therefore less strict than before $(p \leq 0.1)$ and included some lines with rye chromosome 1 chromatin resistant to $R$. padi. S. avenae weights were significantly reduced on 11 genotypes $(d f=22,211 ; F=$ 3.52; $p \leq 0.0001$ ) compared to Pavon F76 (Table 2). The weight of $S$. avenae feeding on adult plants of the 1AL.1RS $\mathrm{Rm}_{\mathrm{am}}$ genotype was significantly reduced $(p \leq 0.05)$ compared to Pavon F76 (Table 3 ). This line also significantly reduced S. avenae weight by $23.2 \%$ in the Phase 2 seedling test compared to Pavon F76). subset 2: $d f=33,65 ; F=2.32 ; p=0.0019)$. However, only four lines with Ae. speltoides chromatin (7A.7S-L7, 7A.7S-L5, and 7A.7S-Gb5) were significantly less chlorotic than Pavon F76 (Table 1). Statistical differences were observed for the numbers of $S$. graminum developing on the plants $(d f=9,60 ; F=2.37 ; p=0.023)$, weight of the colony $(d f=9,60 ; F=3.24 ; p=0.0029)$ and chlorosis $(d f=9,68 ; F=7.74 ; p<0.0001)$. As in Phase 1 , genotypes 7A.7S-L7, 7A.7S-L5, and 7A.7S-Gb5 showed less leaf chlorosis than Pavon F76 (Table 4), and 7A.7S-L5 also significantly reduced S. graminum colony weight by $67.7 \%$ and the number of $S$. graminum, compared to Pavon F76. Genotypes 7A.7S-L7 and 7A.7S-Gb5 showed low average levels of chlorosis (0.9 \% and 2.3\%, respectively), but did not significantly reduce $S$. graminum numbers or colony weight. Line 7A.7S-S3 showed a susceptible response, as it also did in the Phase 1 test (Tables 1,4). For the four genotypes with low chlorosis, one degree of freedom contrasts showed differences in the number of $S$. graminum per plant between genotypes 7A.7S-L7 and 7A.7S-L5, and between 7A.7S-L7 and GRS-1201 ( $\mathrm{p}<0.01)$, but no significant differences were observed between the four lines in terms of aphid colony weight or chlorosis (Table 5). Therefore these results indicate that genotypes 7A.7S-L5 and 7A.7S-Gb5 performed similarly to the resistant control GRS-1201 in all aspects studied (Table 5).

\section{Discussion}

Certain translocation and substitution lines with rye chromatin in chromosome 1 were resistant to both $R$. padi and $S$. avenae, but no $1 \mathrm{R}$ or $1 \mathrm{RS}$ line was strongly resistant to $S$. graminum biotype E. However, previous studies have shown that the $1 \mathrm{RS}$ chromosome arm carries the Gb2 and Gb6 S. graminum resistance genes from Insave rye (Sebesta and Wood 1978; Porter et al. 1991; Lu et al. 2010). Chromosome 1R from the E12165 wheat substitution line incorporated into Pavon F76 carries gene(s) for $R$. padi and S. avenae resistance. Most genotypes with this $1 \mathrm{R}_{\mathrm{e}}$ source reduced the weights of $R$. padi or $S$. avenae, and genotypes $1 \mathrm{R}_{\mathrm{e}}(1 \mathrm{~A}), 1 \mathrm{R}_{\mathrm{e}}(1 \mathrm{~B}), 1 \mathrm{AL} \cdot 1 \mathrm{RS}_{\mathrm{e}}$, and $_{1 \mathrm{BL}} \cdot 1 \mathrm{RS}_{\mathrm{e}}$ 
from the wheat line E12165 with a 1R(1D) substitution from a cross between Panda triticale and a CIMMYT wheat line. Both sources of resistance are very useful in breeding programs, since 1RS has previously been reported to increase yield in the Pavon F76 background (Kim et al. 2004). Of the two lines resistant to both R. padi and S. avenae $\left(1 \mathrm{AL} \cdot 1 \mathrm{RS}_{\mathrm{e}}\right.$ and $\left.1 \mathrm{BL} \mathrm{v} \cdot 1 \mathrm{RS} \mathrm{S}_{\mathrm{e}}\right), 1 \mathrm{AL} \cdot 1 \mathrm{RS}_{\mathrm{e}}$ is preferred because it has less of a negative effect on baking quality (Kumlay et al. 2003). Genotypes $1 \mathrm{R}_{\mathrm{pr}}(1 \mathrm{D})$ and $1 \mathrm{R}_{\mathrm{pr}} \cdot 1 \mathrm{D}_{5+10-2}(1 \mathrm{D})$, from Presto triticale, also expressed resistance to $R$. padi and S. avenae. The 1R chromosome from Presto was engineered to improve bread-making quality in hexaploid triticale, and later, genotypes $1 R_{\mathrm{pr}}(1 \mathrm{D})$ and $1 \mathrm{R}_{\mathrm{pr}} \cdot 1 \mathrm{D}_{5+10-2}(1 \mathrm{D})$ were produced in the Pavon F76 background (Lukaszewski 2006).

212 The 1RS chromosome was present in all of the lines that significantly reduced the weight of R. padi and/or S. avenae in Phase 2 tests, suggesting that gene(s) for resistance are located on 1RS. Interestingly, the genotype carrying the 1RS translocation from Amigo wheat (1AL.1RS $\left.\mathrm{am}_{\mathrm{am}}\right)$ showed resistance to $S$. avenae both at seedling and adult stages. Other studies have reported that Amigo wheat is resistant to S. avenae (Lowe 1981; Hu et al. 2004), and our results suggest that this resistance is conferred by $1 \mathrm{RS}$ from Insave rye. Unlike $R$. padi and S. graminum, which cause significant damage at early plant stages, S. avenae normally has a higher reproductive rate when feeding on flowering plants (Watt 1979) and causes more deleterious damage to plants in later developmental stages (Voss et al. 1997). It is therefore important to screen for S. avenae resistance in adult plants, but the challenges of keeping plants free of other pests and diseases, and the difficulty in matching the phenology of test plants, make adult plant testing much more demanding than seedling tests. This is perhaps the reason why few studies of adult plant resistance to $S$. avenae have been conducted under controlled conditions. Of the lines expressing $S$. avenae resistance as seedlings, only the $1 \mathrm{AL} .1 \mathrm{RS}_{\mathrm{am}}$ translocation line from Amigo wheat significantly reduced S. avenae weights on adult plants. Similar results were obtained by Migui and Lamb (2004) when they compared resistance effects on S. avenae from seedlings and adult plants of Triticum monococcum L. accessions. They hypothesized that the lower resistance of adult plants was due to a reduction in hydroxamic acids (Hx) during wheat plant growth and development (Migui and Lamb 2004). However, Hx concentration is still relatively high in the young tissues of mature plants, such as in emerging flag leaves (Thackray et al. 1990; Copaja et al. 1999). Several studies have shown a strong negative correlation between cereal aphid performance, including $S$. avenae, and Hx concentrations in young wheat plants (Thackray et al. 1990; Leszczynski and Dixon 1992; Givovich and Niemeyer 1994; Hansen 2006), whereas other have shown no correlation between Hx concentration and $S$. avenae performance (Nicol and Wratten 1997; Castaneda et al. 2010).

Hx concentrations are unlikely to explain the resistance patterns that we found in lines with a Pavon F76 background. et al. 1992). Furthermore, the genes governing the accumulation of Hx are located on hexaploid wheat chromosome groups 4 and 5, and on rye chromosomes 5R and 7R (Niemeyer and Jerez 1997; Nomura et al. 2002 ; Nomura et al. 2003), whereas rye resistance to $S$. avenae, and $R$. padi was only found in chromosome 1 substitution and translocation lines. Since the plant genotypes into which the alien material was incorporated have low $\mathrm{Hx}$ concentrations, both seedling and adult plant resistance is most likely due to other physiological processes, unless 
there are epistatic effects of resistance genes on Hx genes. Further investigation is needed to elucidate the causes of seedling resistance and the lack of resistance in the adult stage.

242 Tyler et al. (1985) identified a source of resistance to S. graminum originating from Ae. speltoides in several wheat substitution lines. The resistance gene in those lines was later designated as Gb5 (Tyler et al. 1987). One substitution line (CI17884) was utilized to derive the KS90H445 wheat translocation line. This line lacked suitable agronomic performance (Friebe et al. 1991). Therefore, Lukaszewski (1995) transferred the Gb5 chromatin from KS90H445 to Pavon 76 through homoeologous recombination with the ph1b mutation, resulting in, among others, the lines 7A.7SS3, 7A.7S-L7, 7A.7S-L5, and 7A.7S-Gb5. Dubcovski et al. (1998) characterized 7A.7S-S3 and 7A.7S-Gb5 as carrying the Lr47 and Gb5 resistance genes, respectively. The substitution line CI17884 demonstrates moderate antibiotic effects on S. graminum biotype E (Tyler et al. 1985), and in our experiments, genotype 7A.7S-Gb5 gave similar results combined with low chlorosis levels. Genotype 7A.7S-L7 had significantly lower levels of chlorosis compared to Pavon F76, but significantly higher numbers of S. graminum per plant when compared to 7A.7S-L5 and the resistant check GRS-1201. The differences between these recombinant derived lines suggest that genotype 7A.7S-L7 is predominantly tolerant to S. graminum feeding, and that the chromatin transferred to Pavon F76 has more than one locus responsible for S. graminum resistance, which may have been separated during its transfer to Pavon F76. Further evaluations are needed to investigate the two categories of resistance in 7A.7S-L7, 7A.7S-L5, and 7A.7S-Gb5 to better clarify such differences. As expected, the line $1 \mathrm{AL} .1 \mathrm{RS}_{\mathrm{am}}$ containing Gb2 was susceptible to S. graminum biotype E, whereas the GRS-1201 control containing Gb6 was resistant. Both genotypes are derived from the rye cultivar Insave. Lu et al. (2010) used molecular mapping to show that they are non-allelic genes and that Insave must be genetically heterogeneous.

The usefulness of the resistant genotypes we found, especially those with resistance to $R$. padi and $S$. avenae, will be largely determined by the genetic variation in aphid populations. It is well known that aphid virulence can vary in different geographic areas, as demonstrated for the Russian wheat aphid (Haley et al. 2004; Smith et al. 2004a; Weiland et al. 2008). Several unique S. graminum biotypes in the USA differ in virulence patterns to resistant cultivars (Burd and Porter 2006), and were present before resistant cultivars were grown (Porter et al. 1997). Variation in host responses also exist in different S. avenae populations (Lowe 1981; Caillaud et al. 1995 ; Xu et al. 2011), but to our knowledge, no studies have compared virulence patterns among different $R$. padi populations. Our results indicate that resistance to $R$. padi and $S$. avenae can be transferred from rye into wheat depending on the chromosome arm of wheat that is substituted and the source of the alien chromatin. We used reduced aphid growth in no-choice assays as an estimate of resistance levels. How this translates into reduced population growth remains to be determined. There may also be a component of antixenosis that would be expressed more if aphids were not confined. Future field evaluations need to be conducted to determine the degree of aphid infestation and to estimate yield losses due to aphid damage in this resistant germplasm. padi and S. avenae in $1 \mathrm{AL} .1 \mathrm{RS}_{\mathrm{e}}$ and $1 \mathrm{AL} .1 \mathrm{RS}_{\mathrm{am}}$ translocation lines. The high levels of S. graminum resistance found in the Ae. speltoides recombinant-derived lines require further investigation, since it is advantageous to combine 
resistance mechanisms to reduce damage levels and to improve the durability of resistance. The sources of resistance to R. padi, S. avenae, and S. graminum identified in this study have great potential for use by breeding programs aiming to transfer aphid resistance into cultivars. Resistance is already present in adapted spring wheat germplasm, and, in the case of R. padi and S. avenae, single genotypes can be used as resistance sources.

Acknowledgments: We thank the Monsanto's Beachell-Borlaug International Scholars Program for financing this research project. The Swedish Foundation for Strategic Environmental Research (Mistra) through the PlantComMistra program is acknowledged for support. We would also like to thank for technical support provided by Dr. Vehbo Hot (SLU) and Ms. Lina Aguirre (KSU) and to Dr. Jan-Eric Englund (SLU) for his valuable advice on the statistical analyses. E. Quilligan provided editing assistance.

\section{References}

Berzonsky WA, Ding H, Haley SD, Harris MO, Lamb RJ, McKenzie RIH, Ohm HW, Patterson FL, Peairs FB, Porter DR, Ratcliffe RH, Shanower TG (2003) Breeding wheat for resistance to insects. Plant Breeding Reviews 22:221-296

Blackman RL, Eastop VF (2007) Taxonomic Issues. In: Van Emden HF and Harrington R (eds) Aphids as Crop Pests. pp 1-29

Brunell MS, Lukaszewski AJ, Whitkus R (1999) Development of arm specific RAPD markers for rye chromosome 2R in wheat. Crop Sci 39 (6):1702-1706

Burd JD, Porter DR (2006) Biotypic diversity in greenbug (Hemiptera: Aphididae): characterizing new virulence and host associations. J Econ Entomol 99 (3):959-965

Caillaud CM, Dedryver CA, DiPietro JP, Simon JC, Fima F, Chaubet B (1995) Clonal variability in the response of Sitobion avenae (Homoptera: Aphididae) to resistant and susceptible wheat. Bull Entomol Res 85 (2):189_ 195

Castaneda LE, Figueroa CC, Nespolo RF (2010) Do insect pests perform better on highly defended plants? Costs and benefits of induced detoxification defences in the aphid Sitobion avenae. J Evol Biol 23 (11):2474-2483. doi:10.1111/j.1420-9101.2010.02112.x

Copaja SV, Nicol D, Wratten SD (1999) Accumulation of hydroxamic acids during wheat germination. Phytochemistry 50 (1):17-24. doi:10.1016/s0031-9422(98)00479-8

Di Pietro JP, Caillaud CM, Chaubet B, Pierre JS, Trottet M (1998) Variation in resistance to the grain aphid, Sitobion avenae (Sternorhynca : Aphididae), among diploid wheat genotypes: Multivariate analysis of agronomic data. Plant Breeding 117 (5):407-412. doi:10.1111/j.1439-0523.1998.tb01964.x 
Dubcovsky J, Lukaszewski AJ, Echaide M, Antonelli EF, Porter DR (1998) Molecular characterization of two Triticum speltoides interstitial translocations carrying leaf rust and greenbug resistance genes. Crop Sci 38 (6):1655-1660

Franzen LD, Gutsche AR, Heng-Moss TM, Higley LG, Macedo TB (2008) Physiological responses of wheat and barley to Russian wheat aphid, Diuraphis noxia (Mordvilko) and bird cherry-oat aphid, Rhopalosiphum padi (L.) (Hemiptera: Aphididae). Arthropod-Plant Inte 2 (4):227-235. doi:10.1007/s11829-008-9048-1

Friebe B, Jiang J, Raupp WJ, McIntosh RA, Gill BS (1996) Characterization of wheat-alien translocations conferring resistance to diseases and pests: Current status. Euphytica 91 (1):59-87

Friebe B, Mukai Y, Dhaliwal HS, Martin TJ, Gill BS (1991) Identification of alien chromatin specifying resistance to wheat streak mosaic and greenbug in wheat germ plasm by C-banding and in situ hybridization. Theor Appl Genet 81 (3):381-389. doi:10.1007/bf00228680

Givovich A, Niemeyer HM (1994) Effect of hydroxamic acids on feeding behaviour and performance of cereal aphids (Hemipetra: Aphididae) on wheat. Eur J Entomol 91:371-374

Haley SD, Peairs FB, Walker CB, Rudolph JB, Randolph TL (2004) Occurrence of a new Russian wheat aphid biotype in Colorado. Crop Sci 44 (5):1589-1592

Hansen LM (2006) Effect of 6-methoxybenzoxazolin-2-one (MBOA) on the reproduction rate of the grain aphid (Sitobion avenae F.). J Agric Food Chem 54 (4):1031-1035. doi:10.1021/jf0509005

Hesler LS (2005) Resistance to Rhopalosiphum padi (Homoptera: Aphididae) in three triticale accessions. J Econ Entomol 98 (2):603-610

Hesler LS, Haley SD, Nkongolo KK, Peairs FB (2007) Resistance to Rhopalosiphum padi (Homoptera: Aphididae) in triticale and triticale-derived wheat lines resistant to Diuraphis noxia (Homoptera: Aphididae). J Entomol Sci 42 (2):217-227

Hesler LS, Tharp CI (2005) Antibiosis and antixenosis to Rhopalosiphum padi among triticale accessions. Euphytica 143 (1-2):153-160. doi:10.1007/s10681-005-3060-7

Hu X, Zhao H, Heimbach U, Thieme T, Li J, Zhang Y, Liu B, Li D, Hu Z (2004) Study on cereal aphid resistance on three winter wheat cultivars introduced into China. Acta Bot Boreali-Occidential Sinica 24 (7):1221-1226

Kieckhefer RW, Gellner JL (1992) Yield losses in winter wheat caused by low-density cereal aphid populations. Agron J 84 (2):180-183

Kim W, Johnson JW, Baenziger PS, Lukaszewski AJ, Gaines CS (2004) Agronomic effect of wheat-rye translocation carrying rye chromatin (1R) from different sources. Crop Sci 44 (4):1254-1258

Kumlay AM, Baezinger PS, Gill KS, Shelton DR, Graybosch RA, Lukaszewski AJ, Wesenberg DM (2003) Understanding the effect of rye chromatin in bread wheat. Crop Sci 43 (5):1643-1651 
Leszczynski B, Dixon AFG (1992) Resistance of cereals to aphids - the interaction between hydroxamic acids and glutathione S-transferases in the grain aphid Sitobion avenae (F) (Hom., Aphididade). J Appl Entomol 113 (1):61-67

Liu X, Yang X, Wang C, Wang Y, Zhang H, Ji W (2012) Molecular mapping of resistance gene to English grain aphid (Sitobion avenae F.) in Triticum durum wheat line C273. Theor Appl Genet 124 (2):1-7

Lowe H (1981) Resistance and susceptibility to colour forms of the aphid Sitobion avenae in spring and winter wheats (Triticum aestivum). Ann Appl Biol 99 (1):87-98

Lu H, Rudd JC, Burd JD, Weng Y (2010) Molecular mapping of greenbug resistance genes Gb2 and Gb6 in T1AL.1RS wheat-rye translocations. Plant Breeding. doi:10.1111/j.1439-0523.2009.01722.x

Lukaszewski AJ (1993) Reconstruction in wheat of complete chromosomes 1B and 1R from the 1RS.1BL translocation of 'Kavkaz' origin. Genome 36 (5):821-824

Lukaszewski AJ (1995) Physical distribution of translocation breakpoints in homoeologous recombinants induced by the absence of the Ph1 gene in wheat and triticale. Theor Appl Genet 90 (5):714-719

Lukaszewski AJ (1997) Further manipulation by centric misdivision of the 1RS.1BL translocation in wheat. Euphytica 94 (3):257-261. doi:10.1023/a:1002916323085

Lukaszewski AJ (2000) Manipulation of the 1RS.1BL translocation in wheat by induced homoeologous recombination. Crop Sci 40 (1):216-225

Lukaszewski AJ (2006) Cytogenetically engineered rye chromosomes $1 \mathrm{R}$ to improve bread-making quality of hexaploid triticale. Crop Sci 46 (5):2183-2194. doi:10.2135/cropsci2006.03.0135

Lukaszewski AJ (2008) Unexpected behavior of an inverted rye chromosome arm in wheat. Chromosoma 117 (6):569-578. doi:10.1007/s00412-008-0174-4

Lukaszewski AJ, Rybka K, Korzun V, Malyshev SV, Lapinski B, Whitkus R (2004) Genetic and physical mapping of homoeologous recombination points involving wheat chromosome $2 \mathrm{~B}$ and rye chromosome $2 \mathrm{R}$. Genome 47 (1):36-45. doi:10.1139/g03-089

Migui SM, Lamb RJ (2003) Patterns of resistance to three cereal aphids among wheats in the genus Triticum (Poaceae). Bull Entomol Res 93 (4):323-333. doi:10.1079/ber2003246

Migui SM, Lamb RJ (2004) Seedling and adult plant resistance to Sitobion avenae (Hemiptera: Aphididae) in Triticum monococcum (Poaceae), an ancestor of wheat. Bull Entomol Res 94 (1):35-46. doi:10.1079/ber2003278

Nicol D, Copaja SV, Wratten SD, Niemeyer HM (1992) A screen of worldwide wheat cultivars for hydroxamic acid levels and aphid antixenosis. Ann Appl Biol 121 (1):11-18. doi:10.1111/j.1744-7348.1992.tb03982.x 
Nicol D, Wratten SD (1997) The effect of hydoroxamic acid concentration at late growth stages of wheat on the performance of the aphid Sitobion avenae. Ann Appl Biol 130 (3):387-396. doi:10.1111/j.17447348.1997.tb07669.x

Niemeyer HM, Jerez JM (1997) Chromosomal location of genes for hydroxamic acid accumulation in Triticum aestivum L. (wheat) using wheat aneuploids and wheat substitution lines. Heredity 79 (1):10-14

Nomura T, Ishihara A, Imaishi H, Ohkawa H, Endo TR, Iwamura H (2003) Rearrangement of the genes for the biosynthesis of benzoxazinones in the evolution of Triticeae species. Planta 217 (5):776-782. doi: $10.1007 / \mathrm{s} 00425-003-1040-5$

Nomura TN, Ishihara AI, Imaishi HI, Endo TE, Ohkawa HO, Iwamura HI (2002) Molecular characterization and chromosomal localization of cytochrome P450 genes involved in the biosynthesis of cyclic hydroxamic acids in hexaploid wheat. Mol Genet Genomics 267 (2):210-217. doi:10.1007/s00438-002-0653-x

Porter DR, Burd JD, Shufran KA, Webster JA, Teetes GL (1997) Greenbug (Homoptera: Aphididae) biotypes: selected by resistant cultivars or preadapted opportunists? J Econ Entomol 90 (5):1055-1065

Porter DR, Harris MO, Hesler LS, Puterka GJ (2009) Insects which challenge global wheat production. In: Carver BF (ed) Wheat Science and Trade. Wiley-Blackwell, Iowa, USA, pp 189-201

Porter DR, Webster JA, Burton RL, Puterka GJ, Smith EL (1991) New sources of resistance to greenbug in wheat. Crop Sci 31 (6):1502-1504

Rabinovich SV (1998) Importance of wheat-rye translocations for breeding modern cultivars of Triticum aestivum L. (Reprinted from Wheat: Prospects for global improvement, 1998). Euphytica 100 (1-3):323-340

Riedell WE, Kieckhefer RW, Langham MAC, Hesler LS (2003) Root and shoot responses to bird cherry-oat aphids and barley yellow dwarf virus in spring wheat. Crop Sci 43 (4):1380-1386

SAS Institute Inc. (2009) SAS/STAT ${ }^{\circledR} 9.2$ User's guide. SAS Institute Inc, Cary, NC, USA

Sebesta E, Wood E (1978) Transfer of greenbug resistance from rye to wheat with X-rays. Agronomy abstracts 70:61-62

Skovmand B, Villareal RL, van Ginkel M, Rajaram S, Ortiz-Ferrara G (1997) Semidwarf bread wheats: names, parentages, pedigrees and origins. CIMMYT, Mexico, D. F.

Smith CM, Belay T, Stauffer C, Stary P, Kubeckova I, Starkey S (2004a) Identification of Russian wheat aphid (Homoptera: Aphididae) populations virulent to the Dn4 resistance gene. J Econ Entomol 97 (3):1112-1117. doi:10.1603/0022-0493(2004)097[1112:iorwah]2.0.co;2

Smith CM, Havlickova H, Starkey S, Gill B, Holubec V (2004b) Identification of Aegilops germplasm with multiple aphid resistance. Euphytica 135 (3):265-273 
Thackray DJ, Wratten SD, Edwards PJ, Niemeyer HM (1990) Resistance to the aphids Sitobion avenae and Rhopalosiphum padi in Gramineae in relation to hydroxamic acid levels. Ann Appl Biol 116 (3):573-582. doi:10.1111/j.1744-7348.1990.tb06640.x

Tyler JM, Webster JA, Merkle OG (1987) Designations for genes in wheat germplasm conferring greenbug resistance. Crop Sci 27 (3):526-527

Tyler JM, Webster JA, Smith EL (1985) Biotype E greenbug resistance in WSMV resistant wheat germplasm lines. Crop Sci 25 (4):686-688

Voss TS, Kieckhefer RW, Fuller BW, McLeod MJ, Beck DA (1997) Yield losses in maturing spring wheat caused by cereal aphids (Homoptera: Aphididae) under laboratory conditions. J Econ Entomol 90 (5):1346-1350

Watt A (1979) The effect of cereal growth stages on the reproductive activity of Sitobion avenae and Metopolophium dirhodum. Ann Appl Biol 91 (2):147-157

Weiland AA, Peairs FB, Randolph TL, Rudolph JB, Haley SD, Puterka GJ (2008) Biotypic diversity in Colorado Russian wheat aphid (Hemiptera: Aphididae) populations. J Econ Entomol 101 (2):569-574. doi:10.1603/0022-0493(2008)101[569:bdicrw]2.0.co;2

Weng Y, Li W, Devkota RN, Rudd JC (2005) Microsatellite markers associated with two Aegilops taushii-derived greenbug resistance loci in wheat. Theor Appl Genet 110:462-469

Xu ZH, Chen JL, Cheng DF, Sun JR, Liu Y, Francis F (2011) Discovery of English grain aphid (Hemiptera: Aphididae) biotypes in China. J Econ Entomol 104 (3):1080-1086

Zadoks JC, Chang TT, Konzak CF (1974) A decimal code for the growth stages of cereals. Weed Res 14 (6):415-421 
Table 1. R. padi and S. avenae weights, and percent leaf chlorosis response to S. graminum relative to the control

Pavon F76 in Phase 1 seedling experiments, and subset number in which lines were tested for each aphid species.

\begin{tabular}{|c|c|c|c|c|c|c|c|c|}
\hline \multirow{2}{*}{ Genotype $^{\dagger}$} & \multicolumn{3}{|c|}{ R. padi } & \multicolumn{3}{|c|}{ S. avenae } & \multicolumn{2}{|c|}{ S. graminum } \\
\hline & \multicolumn{2}{|c|}{ \% Pavon F76 ${ }^{\ddagger}$} & Subset & \multicolumn{2}{|c|}{ \% Pavon F76 } & Subset & \%Pavon F76" & Subset \\
\hline \multicolumn{9}{|c|}{ SUBSTITUTION LINES } \\
\hline $1 \mathrm{R}_{\mathrm{e}}(1 \mathrm{~A})$ & 81.8 & & 1 & 127.8 & $(+)$ & 1 & 89.5 & 1 \\
\hline $1 R_{e}(1 B)$ & 105.7 & & 1 & 69.8 & + & 1 & 121.3 & 1 \\
\hline $1 \mathrm{R}_{\mathrm{e}}(1 \mathrm{D})$ & 91.5 & & 1 & 128.4 & $(+)$ & 1 & 110.2 & 1 \\
\hline MA1S.1RL $\mathrm{e}_{\mathrm{e}}(1 \mathrm{~A})$ & 88.9 & & 1 & 119.4 & & 1 & 111.7 & 1 \\
\hline MA1S.1RL $_{e}(1 \mathrm{~B})$ & 90.9 & & 1 & 130.4 & $(+)$ & 1 & 83.6 & 1 \\
\hline MA1S.1RL $_{e}(1 \mathrm{D})$ & 87.3 & & 1 & 90.7 & & 1 & 120.6 & 1 \\
\hline $1 R_{p r}(1 D)$ & 74.2 & $* *$ & 1 & 89.2 & & 1 & 160.5 & 1 \\
\hline $1 \mathrm{R}_{\mathrm{pr}} \cdot 1 \mathrm{D}_{5+10-2}(1 \mathrm{D})$ & 71.2 & $* *$ & 1 & 73.8 & & 1 & 90.2 & 1 \\
\hline $1 \mathrm{R}_{\mathrm{rec}}(1 \mathrm{~A})$ & 105.1 & & 1 & 108.5 & & 1 & 84.3 & 1 \\
\hline $1 \mathrm{R}_{\mathrm{rec}}(1 \mathrm{~B})$ & 115.7 & & 1 & 137.7 & $(+)$ & 1 & 85.1 & 1 \\
\hline $1 \mathrm{R}_{\mathrm{rec}}(1 \mathrm{D})$ & 85.6 & & 1 & 107.0 & & 1 & 114.6 & 1 \\
\hline $1 \mathrm{R}_{\mathrm{inv}}(1 \mathrm{~A})$ & 83.4 & & 1 & 80.7 & & 1 & 56.2 & 1 \\
\hline $2 \mathrm{R}_{\mathrm{rec}}(2 \mathrm{~B})$ & 91.6 & & 1 & 137.8 & $(+)$ & 1 & 156.1 & 1 \\
\hline \multicolumn{9}{|c|}{ TRANSLOCATION LINES } \\
\hline $1 \mathrm{AL} .1 \mathrm{RS}_{\mathrm{e}}$ & 75.7 & $* *$ & 2 & 79.5 & + & 2 & 116.9 & 1 \\
\hline $1 \mathrm{AL} .1 \mathrm{RS}_{\mathrm{am}}$ & 104.1 & & 2 & 107.7 & & 1 & 95.4 & 1 \\
\hline $1 \mathrm{AL} .1 \mathrm{RS}_{\mathrm{v}}$ & 95.6 & & 2 & 82.0 & & 2 & 117.6 & 1 \\
\hline $1 \mathrm{AL} .1 \mathrm{RS}_{\mathrm{rh}}$ & 85.5 & & 2 & 77.0 & + & 2 & 100.6 & 1 \\
\hline $1 \mathrm{BL} .1 \mathrm{RS}_{\mathrm{e}}$ & 70.6 & $* *$ & 2 & 78.8 & + & 2 & 124.3 & 1 \\
\hline $1 \mathrm{BL}_{\mathrm{v}} \cdot 1 \mathrm{RS}_{\mathrm{e}}$ & 71.5 & $* *$ & 3 & 73.0 & $*$ & 2 & 85.8 & 1 \\
\hline $1 \mathrm{BL} .1 \mathrm{RS}_{\mathrm{cim}}$ & 117.4 & & 2 & 133.2 & $(*)$ & 1 & 162.7 & 1 \\
\hline $1 \mathrm{BL} .1 \mathrm{RS}_{\mathrm{gnr}}$ & 92.4 & & 2 & 130.1 & $(+)$ & 1 & 62.1 & 1 \\
\hline $1 B L .1 \mathrm{RS}_{\mathrm{v}}$ & 95.6 & & 2 & 103.2 & & 2 & 85.1 & 1 \\
\hline 1BL.1RS ${ }_{\mathrm{i}}$ & 92.3 & & 2 & 96.7 & & 2 & 91.0 & 1 \\
\hline $1 \mathrm{BL} .1 \mathrm{RS}_{\mathrm{i}}$ & 101.2 & & 4 & 86.7 & & 3 & 125.1 & 2 \\
\hline MA1 & 76.8 & $* *$ & 2 & 100.4 & & 2 & 123.1 & 1 \\
\hline MA2 & 84.7 & & 2 & 110.1 & & 2 & 105.0 & 1 \\
\hline Tel & 91.6 & & 2 & 81.9 & & 2 & 81.4 & 1 \\
\hline $\mathrm{Te} 2$ & 90.3 & & 2 & 82.0 & & 2 & 99.1 & 1 \\
\hline $1 B_{i}$ & 99.0 & & 4 & 86.7 & & 3 & 101.8 & 2 \\
\hline $1 \mathrm{R}_{\mathrm{i}}(1 \mathrm{~B})$ & 110.8 & & 1 & 125.5 & $(+)$ & 1 & 86.5 & 1 \\
\hline
\end{tabular}




\begin{tabular}{|c|c|c|c|c|c|c|c|c|c|}
\hline $1 \mathrm{DL} .1 \mathrm{RS}_{\mathrm{bb}}$ & 85.7 & & 2 & 77.5 & + & 2 & 97.6 & & 1 \\
\hline $1 \mathrm{DL} .1 \mathrm{RS}_{\mathrm{w}}$ & 65.2 & $* *$ & 2 & 86.4 & & 2 & 90.2 & & 1 \\
\hline $1 \mathrm{DL} .1 \mathrm{RS}_{\mathrm{e}}$ & 90.2 & & 2 & 92.1 & & 2 & 101.3 & & 1 \\
\hline $1 \mathrm{DL} .1 \mathrm{RS}_{\mathrm{v}}$ & 101.2 & & 2 & 103.4 & & 2 & 118.3 & & 1 \\
\hline $1 \mathrm{AS} .1 \mathrm{RL}_{\mathrm{e}}$ & 95.0 & & 3 & 86.2 & & 2 & 84.90 & & 2 \\
\hline $1 \mathrm{BS} .1 \mathrm{RL}_{\mathrm{e}}$ & 88.8 & & 3 & 93.0 & & 2 & 69.71 & & 2 \\
\hline $1 \mathrm{DS} .1 \mathrm{RL}_{\mathrm{e}}$ & 75.6 & $* *$ & 3 & 96.7 & & 2 & 130.4 & & 2 \\
\hline $1 \mathrm{DS} .1 \mathrm{RL}_{\mathrm{bb}}$ & 89.9 & & 3 & 92.0 & & 2 & 80.4 & & 2 \\
\hline $1 \mathrm{AS} . \# 2 \mathrm{~L}$ & 96.8 & & 4 & 89.2 & & 3 & 58.1 & & 2 \\
\hline 1AL.1RS+1DL.1RS & 96.0 & & 4 & 104.6 & & 3 & 76.8 & & 2 \\
\hline $2 \mathrm{BL} .2 \mathrm{RS}_{\mathrm{cs}}$ & 94.2 & & 3 & 103.6 & & 2 & 103.6 & & 2 \\
\hline $2 \mathrm{AS} .2 \mathrm{RL}_{\mathrm{cs}}$ & 115.4 & & 4 & 111.7 & & 4 & 105.4 & & 2 \\
\hline $2 \mathrm{BS} .2 \mathrm{RL}_{\mathrm{cs}}$ & 96.8 & & 3 & 107.4 & & 2 & 50.0 & & 2 \\
\hline $2 \mathrm{BS} .2 \mathrm{RL}_{\mathrm{bl}}$ & 84.3 & & 3 & 103.5 & & 2 & 113.4 & & 2 \\
\hline $2 \mathrm{BS} .2 \mathrm{RL}_{\mathrm{cs}}$ & 102.7 & & 4 & 109.4 & & 3 & 88.4 & & 2 \\
\hline 3 DL. $3 \mathrm{RS}_{\mathrm{rh}}$ & 103.0 & & 3 & 111.5 & & 3 & 84.0 & & 2 \\
\hline 3DL.3RS $\mathrm{cs}$ & 92.7 & & 3 & 86.5 & & 3 & 62.5 & & 2 \\
\hline $3 \mathrm{DS} .3 \mathrm{RL}_{\mathrm{cs}}$ & 81.1 & & 3 & 105.2 & & 3 & 120.6 & & 2 \\
\hline $4 \mathrm{~A}_{\text {ril }}$ & 106.0 & & 1 & 157.4 & $(* *)$ & 1 & 150.1 & & 1 \\
\hline $5 \mathrm{AL} .5 \mathrm{RS}_{\mathrm{cs}}$ & 98.8 & & 3 & 95.6 & & 3 & 85.7 & & 2 \\
\hline $5 \mathrm{BL} .5 \mathrm{RS}_{\mathrm{e}}$ & 90.8 & & 3 & 114.1 & & 3 & 114.3 & & 2 \\
\hline $5 \mathrm{DL} .5 \mathrm{RS}_{\mathrm{rh}}$ & 111.3 & & 4 & 108.3 & & 3 & 133.1 & & 2 \\
\hline 6BS.6RL $\mathrm{bb}_{\mathrm{bb}}$ & 97.3 & & 4 & 115.2 & & 3 & 114.0 & & 2 \\
\hline 7DS.4RL $\mathrm{m}_{\mathrm{m}}$ & 94.3 & & 3 & 111.3 & & 3 & 95.6 & & 2 \\
\hline \multicolumn{10}{|c|}{ RECOMBINANT DERIVED LINES } \\
\hline $1 \mathrm{D}+9$ & 107.8 & & 4 & 136.5 & $(*)$ & 4 & 44.6 & & 2 \\
\hline $\mathrm{T}-9$ & 119.3 & $(*)$ & 4 & 117.0 & & 4 & 108.1 & & 2 \\
\hline $1 \mathrm{D}+4$ & 94.6 & & 4 & 98.4 & & 4 & 96.5 & & 2 \\
\hline $2 \mathrm{D}(\mathrm{s})+2$ & 95.8 & & 3 & 97.6 & & 3 & 67.0 & & 2 \\
\hline $2 \mathrm{D}(\mathrm{s})+4$ & 92.5 & & 3 & 93.2 & & 3 & 108.1 & & 2 \\
\hline 2B.2R & 104.6 & & 4 & 123.6 & $(+)$ & 4 & 75.0 & & 2 \\
\hline 5D.5R-1 & 92.7 & & 3 & 103.1 & & 3 & 77.7 & & 2 \\
\hline 7A.7S-S3 & 101.3 & & 4 & 107.1 & & 3 & 113.4 & & 2 \\
\hline 7A.7S-L7 & 98.1 & & 4 & 98.7 & & 3 & 31.2 & $*$ & 2 \\
\hline 7A.7S-L5 & 92.3 & & 4 & 90.2 & & 3 & 0.0 & $* *$ & 2 \\
\hline 7A.7S-Gb5 & 110.3 & & 4 & 88.5 & & 3 & 31.2 & $*$ & 2 \\
\hline
\end{tabular}


424 'Subscripts for genotypes: e=E12165; pr=Presto triticale; rec=Reconstructed from Kavkaz; inv=Inverted E12165 long arm; am=Amigo wheat; v=Veery; cim=E12169; gnr=Genaro; i=inserted segment; bb=BH1146/Blanco rye;

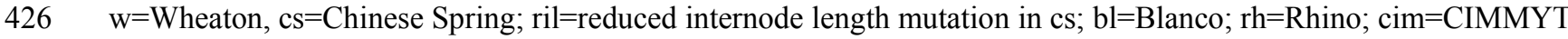

427 E12169 m=Secale montanum Guss.

$428 \quad$ Mean aphid weight on the genotypes divided by the mean aphid weight on Pavon F76 times 100

429 " Mean \% leaf chlorosis of the genotypes relative to the mean \% chlorosis of Pavon F76 times 100

$430+\mathrm{P} \leq 0.1, * \mathrm{P} \leq 0.05 ; * * \mathrm{P} \leq 0.01$ significance levels compared to control Pavon F76 in t-tests, ()$=$ significantly

431 increased aphid weight relative to the control

Table 2. $R$. padi or S. avenae weights relative to the control Pavon F76 and mean R. padi or S. avenae weight $\pm \mathrm{SE}$ in 434 Phase 2 seedling experiments.

\begin{tabular}{|c|c|c|c|c|c|c|c|c|}
\hline \multirow[b]{2}{*}{ Genotype $^{\dagger}$} & \multicolumn{4}{|c|}{ R. padi } & \multicolumn{4}{|c|}{ S. avenae } \\
\hline & $\begin{array}{c}\text { \% Pavon } \\
\text { F76 }^{\ddagger}\end{array}$ & $\begin{array}{c}\text { Weight } \\
\text { (mg) }\end{array}$ & $\pm \mathrm{SE}$ & & $\begin{array}{c}\text { \% Pavon } \\
\text { F76 }^{\ddagger}\end{array}$ & $\begin{array}{c}\text { Weight } \\
\text { (mg) }\end{array}$ & $\pm \mathrm{SE}$ & \\
\hline $1 \mathrm{R}_{\mathrm{e}}(1 \mathrm{~A})$ & 85.3 & 0.251 & 0.0402 & $*$ & 73.7 & 0.166 & 0.0169 & $* *$ \\
\hline $1 \mathrm{R}_{\mathrm{e}}(1 \mathrm{~B})$ & 83.3 & 0.245 & 0.0403 & $* *$ & 73.7 & 0.166 & 0.0168 & $* *$ \\
\hline $1 R_{e}(1 D)$ & 87.4 & 0.257 & 0.0402 & & 70.6 & 0.159 & 0.0170 & $* * *$ \\
\hline MA1S.1RL $L_{e}(1 \mathrm{~A})$ & - & - & - & & 85.3 & 0.192 & 0.0167 & \\
\hline $\operatorname{MA1S.1RL}_{\mathrm{e}}(1 \mathrm{~B})$ & - & - & - & & 79.1 & 0.178 & 0.0170 & \\
\hline MA1S.1RL $_{\mathrm{e}}(1 \mathrm{D})$ & - & - & - & & 90.2 & 0.203 & 0.0166 & \\
\hline $1 \mathrm{R}_{\mathrm{pr}}(1 \mathrm{D})$ & 77.9 & 0.229 & 0.0404 & $* * *$ & 65.7 & 0.148 & 0.0178 & $* * *$ \\
\hline $1 \mathrm{R}_{\mathrm{pr}} \cdot 1 \mathrm{D}_{5+10-2}(1 \mathrm{D})$ & 80.3 & 0.236 & 0.0402 & $* *$ & 75.5 & 0.170 & 0.0170 & $* *$ \\
\hline $1 \mathrm{R}_{\text {inv }}(1 \mathrm{~A})$ & - & - & - & & 68.4 & 0.154 & 0.0170 & $* * *$ \\
\hline $1 \mathrm{AL} .1 \mathrm{RS}_{\mathrm{e}}$ & 81.0 & 0.238 & 0.0402 & $* *$ & 74.2 & 0.167 & 0.0168 & $* *$ \\
\hline $1 \mathrm{AL} .1 \mathrm{RS}_{\mathrm{am}}$ & - & - & - & & 76.8 & 0.173 & 0.0170 & $*$ \\
\hline $1 \mathrm{AL} .1 \mathrm{RS}_{\mathrm{rh}}$ & - & - & - & & 69.7 & 0.157 & 0.0166 & $* * *$ \\
\hline $1 \mathrm{BL} .1 \mathrm{RS}_{\mathrm{e}}$ & 89.7 & 0.264 & 0.0403 & & 71.1 & 0.160 & 0.0170 & $* * *$ \\
\hline $1 \mathrm{BL}_{\mathrm{v}} \cdot 1 \mathrm{RS}_{\mathrm{e}}$ & 75.8 & 0.223 & 0.0404 & $* * *$ & 69.7 & 0.157 & 0.0170 & $* * *$ \\
\hline MA1 & 99.3 & 0.292 & 0.0404 & & 84.4 & 0.190 & 0.0238 & \\
\hline $1 \mathrm{DL} .1 \mathrm{RS}_{\mathrm{bb}}$ & - & - & - & & 90.2 & 0.203 & 0.0169 & \\
\hline $1 \mathrm{DL} .1 \mathrm{RS}_{\mathrm{w}}$ & 102.3 & 0.301 & 0.0403 & & 91.1 & 0.205 & 0.0258 & \\
\hline $1 \mathrm{DL} .1 \mathrm{RS}_{\mathrm{e}}$ & 94.2 & 0.277 & 0.0404 & & 95.5 & 0.215 & 0.0170 & \\
\hline $1 \mathrm{AS} .1 \mathrm{RL}_{\mathrm{e}}$ & 91.5 & 0.269 & 0.0403 & & 87.1 & 0.196 & 0.0171 & \\
\hline $1 \mathrm{BS} .1 \mathrm{RL}_{\mathrm{e}}$ & 92.5 & 0.272 & 0.0402 & & 91.5 & 0.206 & 0.0170 & \\
\hline $1 \mathrm{DS} .1 \mathrm{RL}_{\mathrm{e}}$ & 95.5 & 0.281 & 0.0401 & & 84.0 & 0.189 & 0.0172 & \\
\hline $1 \mathrm{DS} .1 \mathrm{RL}_{\mathrm{bb}}$ & - & - & - & & 82.6 & 0.186 & 0.0170 & \\
\hline Pavon F76 & 100.0 & 0.294 & 0.0403 & & 100.0 & 0.225 & 0.0169 & \\
\hline
\end{tabular}


${ }^{\dagger}$ Subscripts for genotypes: e=E12165; pr= Presto triticale; inv=Inverted E12165 long arm; am=Amigo wheat;

$\mathrm{v}=$ Veery; $\mathrm{bb}=\mathrm{BH} 1146 /$ Blanco rye; $\mathrm{w}=$ Wheaton; $\mathrm{rh}=$ Rhino.

437 Mean aphid weight on the genotypes divided by the mean aphid weight on Pavon F76 times 100

$438 *=\mathrm{P} \leq 0.05 ; * *=\mathrm{P} \leq 0.01 ; * * *=\mathrm{P} \leq 0.0001$ significance levels compared to Pavon F76 in Dunnett's test

440 Table 3. S. avenae weight relative to the control Pavon 76 in the adult plant test.

\begin{tabular}{lc}
\hline Genotype $^{\dagger}$ & \% Pavon F76 \\
\hline $1 \mathrm{R}_{\mathrm{e}}(1 \mathrm{~A})$ & 99.1 \\
$1 \mathrm{R}_{\mathrm{e}}(1 \mathrm{~B})$ & 92.3 \\
$1 \mathrm{R}_{\mathrm{rec}}(1 \mathrm{~A})$ & 119.9 \\
$1 \mathrm{R}_{\mathrm{rec}}(1 \mathrm{~B})$ & 125.7 \\
$1 \mathrm{AL} .1 \mathrm{RS}_{\mathrm{e}}$ & 104.0 \\
$1 \mathrm{AL} .1 \mathrm{RS}_{\mathrm{am}}$ & $78.2^{*}$ \\
$1 \mathrm{AL} .1 \mathrm{RS}_{\mathrm{v}}$ & 108.1 \\
$1 \mathrm{BL} .1 \mathrm{RS}_{\mathrm{e}}$ & 100.6 \\
$1 \mathrm{BL}$ & $1 \mathrm{RS}$ \\
$1 \mathrm{~B} .1 \mathrm{RS}_{\mathrm{v}}$ & 119.2 \\
$1 \mathrm{AS} .1 \mathrm{RL}_{\mathrm{e}}$ & 130.0 \\
$1 \mathrm{BS} .1 \mathrm{RL}_{\mathrm{e}}$ & 107.4
\end{tabular}

441 Subscripts for genotypes: e=E12165; rec=Reconstructed; am=Amigo wheat; v=Veery

$442+$ Mean aphid weight on the genotypes divided by the mean aphid weight on Pavon F76 times 100

$443 * \mathrm{P} \leq 0.05$ significance level compared to Pavon F76 in t-tests

444

445 Table 4. Resistance to S. graminum measured as number of S. graminum developing on plants, percentage of colony 446 weight relative to Pavon F76, colony weight, and percent leaf chlorosis in response to S. graminum feeding.

\begin{tabular}{|c|c|c|c|c|c|c|c|}
\hline Genotype $^{\dagger}$ & $\begin{array}{c}\text { No. } S . \\
\text { graminum }\end{array}$ & $\pm \mathrm{SE}$ & $\begin{array}{c}\text { \% Pavon } \\
\text { F76 }^{\ddagger}\end{array}$ & $\begin{array}{c}\text { Colony } \\
\text { weight } \\
\text { (mg) }\end{array}$ & $\pm \mathrm{SE}$ & $\begin{array}{c}\text { Chlorosis } \\
\text { (\%) }\end{array}$ & $\pm \mathrm{SE}$ \\
\hline $1 \mathrm{R}_{\mathrm{rec}}(1 \mathrm{~A})$ & 39.7 & 8.04 & 62.9 & 5.1 & 0.94 & 60.6 & 8.44 \\
\hline $1 \mathrm{R}_{\text {inv }}(1 \mathrm{~A})$ & 44.5 & 8.66 & 64.8 & 5.2 & 1.01 & 61.2 & 8.45 \\
\hline $2 \mathrm{BS} .2 \mathrm{RL}_{\mathrm{cs}}$ & 47.2 & 7.53 & 82.0 & 6.6 & 0.88 & 43.0 & 7.97 \\
\hline $1 \mathrm{D}+9$ & 43.6 & 9.43 & 77.3 & 6.2 & 1.10 & 84.5 & 9.02 \\
\hline 7A.7S-S3 & 45.4 & 7.09 & 75.3 & 6.1 & 0.83 & 61.0 & 7.97 \\
\hline
\end{tabular}




\begin{tabular}{|c|c|c|c|c|c|c|c|c|c|c|}
\hline 7A.7S-L7 & 48.6 & 8.05 & & 59.5 & 4.8 & 0.94 & & 0.9 & 8.46 & $* * *$ \\
\hline 7A.7S-L5 & 22.7 & 7.09 & $* *$ & 32.3 & 2.6 & 0.83 & $* *$ & 3.0 & 7.97 & $* * *$ \\
\hline 7A.7S-Gb5 & 31.9 & 8.05 & & 54.6 & 4.4 & 0.94 & & 2.3 & 9.02 & $* * *$ \\
\hline GRS-1201 & 20.3 & 8.67 & $* *$ & 32.3 & 2.6 & 1.01 & $* *$ & 1.4 & 9.70 & $* * *$ \\
\hline Pavon F76 & 62.9 & 9.42 & & 100.0 & 8.1 & 1.10 & & 57.6 & 9.70 & \\
\hline
\end{tabular}

447 'Subscripts for genotypes: inv= Inverted E12165 long arm; rec=Reconstructed from Kavkaz; cs=Chinese Spring

448 Weight percentage of Pavon F76 obtained by dividing the mean colony weight of genotypes by the mean colony

449 weight of the control times 100

$450 * *=\mathrm{P} \leq 0.01 ; * * *=\mathrm{P} \leq 0.0001$ significance levels compared to Pavon F76 in Dunnett's test

451

452 Table 5. One degree of freedom contrasts for number of $S$. graminum per plant, aphid colony weight and leaf

453 chlorosis between genotypes carrying Ae. speltoides chromatin and between the resistant control GRS-1201 carrying 454 the $G b 6$ resistance gene.

\begin{tabular}{|c|c|c|c|}
\hline Contrast & $\begin{array}{l}\text { No. } S . \\
\text { graminum }\end{array}$ & Colony Weight & Chlorosis \\
\hline 7A.7S-L7 vs. 7A.7S-L5 & $* *$ & NS & NS \\
\hline 7A.7S-L7 vs. 7A.7S-Gb5 & NS & NS & NS \\
\hline 7A.7S-L7 vs. GRS-1201 & $* *$ & NS & NS \\
\hline 7A.7S-L5 vs. 7A.7S-Gb5 & NS & NS & NS \\
\hline 7A.7S-L5 vs. GRS-1201 & NS & NS & NS \\
\hline 7A.7S-Gb5 vs. GRS-1201 & NS & NS & NS \\
\hline
\end{tabular}

